\title{
Identification of novel drought-tolerant-associated SNPs in common bean (Phaseolus vulgaris)
}

\author{
Emiliano Villordo-Pineda ${ }^{1,2}$, Mario M. González-Chavira ${ }^{1}$, Patricia Giraldo-Carbajo ${ }^{2}$, \\ Jorge A. Acosta-Gallegos ${ }^{1}$ and Juan Caballero-Pérez ${ }^{3 *}$ \\ ${ }^{1}$ Campo Experimental Bajio-Instituto Nacional de Investigaciones Forestales, Agrícolas y Pecuarias, Celaya, México, \\ 2 Unidad de Genética, Departamento de Biotecnología-Biología Vegetal, Escuela Técnica Superior de Ingenieros Agrónomos, \\ Universidad Politécnica de Madrid, Madrid, Spain, ${ }^{3}$ Facultad de Química, Universidad Autónoma de Querétaro, Querétaro, \\ Mexico
}

\section{OPEN ACCESS}

Edited by:

Georgina Hernandez,

Centro de Ciencias

Genomicas-Universidad Nacional

Autonoma de Mexico, Mexico

Reviewed by:

Elena Bitocchi,

Università Politecnica delle Marche,

Carolina Chavarro

University of Georgia, USA

Daniela Goretti,

University of Milan, Italy

${ }^{*}$ Correspondence:

Juan Caballero-Pérez,

Facultad de Química, Universidad Autónoma de Querétaro, Cerro de las

Campanas S/N, Santiago de Querétaro, Querétaro 76010, Mexico jcaballero@uaq.mx

Specialty section:

This article was submitted to

Plant Genetics and Genomics,

a section of the journal

Frontiers in Plant Science

Received: 13 March 2015 Accepted: 06 July 2015

Published: 21 July 2015

Citation:

Villordo-Pineda E, González-Chavira MM, Giraldo-Carbajo P,

Acosta-Gallegos JA and

Caballero-Pérez J (2015) Identification of novel drought-tolerant-associated

SNPs in common bean (Phaseolus vulgaris). Front. Plant Sci. 6:546. doi: 10.3389/fpls.2015.00546
Common bean (Phaseolus vulgaris L.) is a leguminous in high demand for human nutrition and a very important agricultural product. Production of common bean is constrained by environmental stresses such as drought. Although conventional plant selection has been used to increase production yield and stress tolerance, drought tolerance selection based on phenotype is complicated by associated physiological, anatomical, cellular, biochemical, and molecular changes. These changes are modulated by differential gene expression. A common method to identify genes associated with phenotypes of interest is the characterization of Single Nucleotide Polymorphims (SNPS) to link them to specific functions. In this work, we selected two drought-tolerant parental lines from Mesoamerica, Pinto Villa, and Pinto Saltillo. The parental lines were used to generate a population of 282 families $\left(F_{3: 5}\right)$ and characterized by 169 SNPs. We associated the segregation of the molecular markers in our population with phenotypes including flowering time, physiological maturity, reproductive period, plant, seed and total biomass, reuse index, seed yield, weight of 100 seeds, and harvest index in three cultivation cycles. We observed 83 SNPs with significant association $p<0.0003$ after Bonferroni correction) with our quantified phenotypes. Phenotypes most associated were days to flowering and seed biomass with 58 and 44 associated SNPs, respectively. Thirty-seven out of the 83 SNPs were annotated to a gene with a potential function related to drought tolerance or relevant molecular/biochemical functions. Some SNPs such as SNP28 and SNP128 are related to starch biosynthesis, a common osmotic protector; and SNP18 is related to proline biosynthesis, another well-known osmotic protector.

Keywords: bean, stress, drought, SNP, biomarker, genotyping

\section{Introduction}

Common bean (Phaseolus vulgaris L.) is the most important leguminous crop species for human nutrition because it is a natural source of essential nutrients and proteins in the diet of $\sim 500$ million people in Latin America and Africa (Broughton et al., 2003). Common bean originated in the Americas and diverged into the Mesoamerican and Andean genetic pools before domestication (Gepts, 1998; Mamidi et al., 2011; Bitocchi et al., 2013; Schmutz et al., 2014). The Mesoamerican gene pool includes the Mesoamerican, Durango, Jalisco, and Guatemala races 
(Singh et al., 1991; Díaz and Blair, 2006; Blair et al., 2009; Kwak and Gepts, 2009). The Mesoamerican and Durango races are considered to be a rich genetic source for drought stress resistance (Terán and Singh, 2002b; Singh, 2007).

Drought is the most important abiotic stress limiting cultivar productivity. Drought negatively impacts dry-bean cultivars depending on intensity, type and duration of the stress (Terán and Singh, 2002a,b; Muñoz-Perea et al., 2006). Sixty percent of the worldwide dry-bean production is affected by terminal or intermittent drought (Beebe et al., 2008) and it is the second most important factor in yield reduction after plant diseases (Thung and Rao, 1999; Rao, 2001). We can expect than drought will be increasing in number of events and duration in the principal agriculture regions because of global warming. This will affect negatively the production and therefore food availability (McClean et al., 2011). In particular, tropical regions, where poverty and starvation are important problems, will be more affected (Cavalieri et al., 2011). In Latin America is estimated that drought conditions can reduce seed production to $73 \%$, or lost of production. Even worse, drought effects are increased by other biotic or abiotic factors (Polanía et al., 2012).

Drought resistance and adaptation includes several mechanisms to allow plants survive during dry periods. In general, drought resistance mechanisms can include drought escape; drought avoidance; and drought tolerance (Beebe et al., 2013). Drought escape allows plants to accelerate their cell cycle with an early flowering and maturity, and rapidly relocates metabolites to seed production (Beebe et al., 2013) and away from leaves and shoot tissues (Blum, 2005; Nakayama et al., 2007). Drought avoidance is the capability to keep a high tissue water potential through increased rooting depth, hydraulic conductance reduction, radiation absorption reduction in leaves, water-loss area reduction reduced absorption of radiation by leaf movement, and reduced evaporation surface (leaf area) (Beebe et al., 2013). Drought tolerance is the capability in plants to resist the stress by adjusting cell osmosis, cell plasticity, and cell size (Beebe et al., 2013).

Given common bean importance, the search for genetic markers to increase the efficiency of plant selection is essential. New large-scale modern genotyping technologies such as Single Nucleotide Polymorphism (SNP) arrays or Next Generation Sequencing (NGS) can be correlated with phenotypic data in germplasm collections or other useful populations (Beebe et al., 2013). Those technologies allow us the identification of key loci associated with a stress response or a particular phenotype (i.e., higher product biomass, fast development, etc.) (McClean et al., 2011).

SNPs are abundant and well distributed across the genome and can be used for genotyping with high specificity, reproducibility, and performance (Rafalski, 2002; Hyten et al., 2010; Yan et al., 2010). SNPs can be used in breeding for linkage maps construction, genetic diversity analysis, or marker-phenotype association studies for marker-assisted selection (MAS) (Cortés et al., 2011). More than 30 methods for SNP detection has been developed and applied in different species (Gupta et al., 2008). SNP detection in common bean has been applied using Single Base Extension (SBE) (Gaitán-Solís et al., 2008), Expressed Sequence Tags (EST) (Galeano et al., 2012), NGS (Hyten et al., 2010) and Kompetitive allele-specific PCR (KASP) (Cortés et al., 2011; Goretti et al., 2014). SNP information from common bean has been used to build linkage maps and synteny analysis previously (Galeano et al., 2009a,b, 2012; Shi et al., 2011; Yuste-Lisbona et al., 2012). SNPs have been used for the identification of Quantitative Trait Loci (QTL) associated with drought stress in a $\mathrm{F}_{5: 7}$ population derived from a cross between a Mesoamerican and an Andean bean genotype (Mukeshimana et al., 2014). Cortés et al. (2011) used SNP validation from the EST reported in Galeano et al. (2009a,b) and candidate gene validation to drought adaptation in a set group of bean genotypes analyzed previously by Simple Sequence Repeat (SSR) methods in Blair et al. (2006).

Loci for complex traits have been detected in genome wide association studies (GWAS), and from those, only a small fraction of genetic variants are clearly responsible for the phenotype. Modern statistical methods allow us to identify which variants have a real effects on the phenotype providing associated probabilities (Hormozdiari et al., 2014).

We employed an simplified method derived from GWAS, the Single-Marker Analysis (SMA). This method reports the genotype-phenotype associations in a small population. Our populaton is derived from two drought-resistant lines: Pinto Villa (PV) and Pinto Saltillo (PS). PV and PS are members of the Durango race, and both have been extensively studied because they are drought-resistant in semi-desert areas in Mexico. Both lines were derived independently: $\mathrm{PV}$ is derivate from II-25D-M-34 = II-925-M-29-1 x ('Canario 101' $\times$ Mex-4-2) and PS is derivate from MX $8738={ }^{\prime}$ Hidalgo $77^{\prime} / 4 /^{\prime} \mathrm{MAM}$ 30'/3/'Michoacán 91-A'//BAT 76'//'BAT 93'/'Ecuador 299' (Acosta-Gallegos et al., 1995; Sánchez-Valdez et al., 2004). Both lines are believed to resist drought in different ways (Blair et al., 2009; Beebe et al., 2013; Jimenez-Galindo and AcostaGallegos, 2013), and therefore were selected to observe if some SNPs could explain the differences in stress tolerance possibly associated with production-related phenotypes. We used KASP technology to genotype 282 individuals from this population, which were also quantified for phenotypes to perform a SNPassociation study. This was followed by functional annotation of significantly associated SNPs showing some possible evidence of which genes could be involved in the drought tolerance.

\section{Materials and Methods}

\section{Plant Materials and Experimental Site}

We generated a population of $282 \mathrm{~F}_{3: 5}$ families derived from the cross between two common bean (Phaseolus vulgaris L.) cultivars: Pinto Villa and Pinto Saltillo was used. Both parental genotypes belong to Mesoamerican race Durango (Acosta-Gallegos et al., 1995; Sánchez-Valdez et al., 2004). Population generation was developed from the parental lines to individual $F_{2}$ plants that were bulk advanced to produce $\mathrm{F}_{3}$ seed. In the $\mathrm{F}_{3}$ generation, 289 individual plants were randomly selfed to develop $\mathrm{F}_{3: 4}$ families under normal conditions. Then, the 289 families were advanced to $F_{3: 5}$, each family was randomly divided into two replicates 
(two stressed and two watered) and grown in $17 \times 17$ lattices. For each replicate, the genotypes were sown in $4 \mathrm{~m}$ lines with 60 seeds. Two replicates were watered four times (pre-planting, vegetative stage, during the flowering, and pod filling stages) and two replicates omitted the fourth watering, starting the drought stress. All plants were grown in soil with a well-drained sandy loam (Calceric-Cambisol) with slightly alkaline $\mathrm{pH}$ (between 7.8 and 8.1 ) and $0.046 \%$ organic matter content.

The experiment was conducted between spring-summer 2010 and 2011 (FR-2010, FR-2011) and autumm-winter 2010 (FT2010) at the Bajio Experimental Station of National Institute for Forestry, Agriculture, and Livestock (INIFAP), in Celaya, Guanajuato, Mexico (20 $34^{\prime} 53^{\prime \prime} \mathrm{N}, 100^{\circ} 49^{\prime} 16^{\prime \prime} \mathrm{W}$ and $1775 \mathrm{~m}$ elevation over sea level). The average annual temperatures were 17.7 and $20.8^{\circ} \mathrm{C}$ and the precipitation were 12,223 , and $30 \mathrm{~mm}$ in FR-2010, FT-2010, and FR-2011, respectively (INIFAP Agroclimatic Station Network, http://www.inifap.gob. $\mathrm{mx})$. The stress induced is considered as "terminal" and affected the late stage in development just after flowering time, which directly impacts seed production. At the tropical lowlands on the Pacific, Gulf of Mexico, Central America and the Caribbean, Mesoamerican beans are grown under residual moisture with planting toward the end of the rainy season with soil moisture decreasing toward the end of the crop cycle. Whereas, at the Mexican Plateau the drought is of the intermittent type that often occurs during the reproductive stage, a critical one, and thus a terminal drought treatment mimics up to certain extent drought during the reproductive stage.

We determined relative soil water content (RSWC) using gravimetric methods in two depths: $0-30$ and 30-60 cm (Earl, 2003). RSWC average values were 63 and $68 \%$ in controls and 25 and $28 \%$ in stress. Normal conditions for each replicate were used in both treatments, including mechanical sowing, manual grass removal, and insecticide by aspersion twice (to control the white fly Trialuroides vaporariorum Westwood).

Tissue samples were collected after FR-2011. For each genotype, 10 young leaves from different healthy and undamaged plants were collected and frozen in liquid nitrogen for bulked DNA extraction.

\section{SNP Genotyping}

After samples were freeze-dried and ground, $100 \mathrm{mg}$ were sent for analysis to LGC Genomics (http://www.lgcgenomics.com, Trident Industrial Estate Pindar Road, Hoddesdon Herts, EN11 $0 \mathrm{WZ}, \mathrm{UK})$. LGC Genomics previously genotyped the parental lines Pinto Villa and Pinto Saltillo with an initial 1497 SNPs derived from the common variations observed in $P$. vulgaris as part of the international collaboration between INIFAP and the GCP (Generation Challenge Programme, http://www. generationcp.org). They found that 180 SNPs were polymorphic in our parental lines and designed 169 DNA probes of 31 nucleotides long for validation with competitive allele-specific PCR (currently called KASP ${ }^{\mathrm{TM}}$ ) incorporating a FRET quencher cassette (with fluorescence of either VIC or FAM fluorophores) from KBioscience (later renamed LGC Genomics). The 169 probes were mapped to the reference genome and coordinates are reported in Supplementary Table 1. All genotypes found in our population and both parental lines are reported in Supplementary Table 2 .

\section{Phenotypic Traits}

Days to flowering (DF) and days to physiological maturity (DPM) were recorded as previously described (Acosta-Díaz et al., 2004). DF is the days from seeding to $50 \%$ of the plants shows open flowers. DPM is the days from seeding to $90 \%$ of the pods changed its green color in alt least $50 \%$ of the plants. The reproductive period (RP) was determined by the difference between the days to physiological maturity and the days to flowering $(\mathrm{RP}=\mathrm{DPM}-\mathrm{DF})$.

Adult plants were collected from a meter row section in each plot and dried at $70^{\circ} \mathrm{C}$ for $48 \mathrm{~h}$. The weight was recorded to determine vegetative (seedless) plant biomass (PB) (Acosta-Díaz et al., 2004). Similarly, seeds were dried and weighted to obtain seed biomass $(\mathrm{SB})$. The total biomass $(\mathrm{TB})$ is expressed as $\mathrm{TB}=$ $\mathrm{PB}+\mathrm{SB}$ (Acosta-Díaz et al., 2004). All biomass measurements are in $\mathrm{g} \mathrm{m}^{-2}$. Seed yield (SY) was determined from the total seed weight per area, and recorded in $\mathrm{g} \mathrm{m}^{-2}$. The weight of 100 seeds (100SW) was obtained from a random sample per experimental unit and recorded in grams. The harvest index (HI) was calculated with the formula $\mathrm{HI}=\mathrm{SY} / \mathrm{TB}$ (Rosales-Serna et al., 2004). The reuse index was calculated as RI = SB / TB. All data recorded is reported in Supplementary Table 3.

\section{Genome Sequences}

Genome reference and gene annotation for P. vulgaris L. v1.0 was obtained from the Phytozome website (http://www.phytozome. net/). Genome size is $521.1 \mathrm{Mb}$ represented in 708 scaffolds with 27,197 total loci with 31,638 coding-gene transcripts and 4441 alternative splicing transcripts (Schmutz et al., 2014).

\section{Statistical Analyses}

Using the probe sequence, each SNP was mapped on to the reference genome with the FASTA aligner (Pearson and Lipman, 1988) obtaining the genomic coordinates for 163 SNPs. This information was analyzed with the $\mathrm{R}$ package SNPassoc (González et al., 2007). SNPassoc includes descriptive statistics and exploratory analysis, it also considers in the computation the presence of missing values removing a SNP from the analyses if the observed genotype is below $80 \%$. We used SNPassoc in the calculation of Hardy-Weinberg equilibrium, analysis of association based on generalized linear models (either for quantitative or binary traits), and analysis of multiple SNPs (haplotype and epistasis analysis). In particular, we used the function WGassociation to evaluate each variable for association using a lineal regression model expressed as variable $\sim$ year + treatment + replicate. This model allowed us to block the variation effects between cycles and replicates, in particular, the differences in stress induced because we can expect variation given variation in precipitation per year.

We selected all significant SNPs associated with $P<$ 0.0003 after Bonferrioni correction testing for variables with codominant, dominant, recessive, overdominant, or log-additive effects. 


\section{Functional Analyses}

We evaluated how a SNP is associated with a phenotype by functional annotation. We correlated the genomic coordinates with the gene annotation for the Phaseolus vulgaris L. v1.0. If the SNP was localized inside a coding exon, we evaluated if this change could generated a negative effect such as a premature stop-codon or a non-synonymous mutation. All genes were functionally annotated by comparison with NCBI-NR database and InterproScan with Blast2GO program (Conesa et al., 2005).

SNP impact on protein product was evaluated using PredictSNP (Bendl et al., 2014), a webservice that integrates several commonly used SNP impact programs and databases such as MAPP, PolyPhen, SIFT, SNAP, PhD-SNP, nsSNPanalyzer, and PANTHER.

\section{Results}

\section{Experimental Data Generated}

Our experimental design produced two contrasted groups, the watered control-plants, and the terminal-drought plants. Even when rain precipitation was variable per cycle, water was not enough (the minimal water requirement is $400 \mathrm{~mm}$ ) and the terminal-stress produced a reduction in production as expected (Supplementary Table 3, Supplementary Figure 1). We noted differences in the response in both parental lines, this confirms that the parental lines have differences in the way the stress is tolerated as we are validating at the molecular level (in preparation). The genetic recombination in our population allows less differences between stressed and control plants.

\section{SNP Association Analyses}

The segregation pattern of the 169 polymorphic SNPs was analyzed in the 282 offspring. One hundred sixty three of 169 of these SNPs could be mapped to the reference genome (Supplementary Table 1). A specific position was not found for SNPs: 20, 131, 143, 161, 162, and 169 (Supplementary Table 1), therefore were excluded from the analyzes. The association of each SNP to each one of the quantified variables (SY, 100SW, $\mathrm{DF}, \mathrm{DPM}, \mathrm{RP}, \mathrm{PB}, \mathrm{SB}, \mathrm{TB}, \mathrm{RI}$, and $\mathrm{HI}$ ) was evaluated with the R package SNPassoc. Supplementary Table 4 shows the $P$ values computed for each possible association between a SNP and the variable in different genetic models tested. With a $P$-value threshold of 0.0003 after Bonferroni correction, 257 statistically significant associations, involving 83 SNPs were identified (Table 1). Briefly, 58 SNPs were associated with flowering time, 44 with seed biomass, 19 with 100 -seed weight, 42 with reproductive period, 37 with reuse index, 40 with total biomass, 8 with physiological maturity time, and 1 with harvest index (Table 2).

From those, 21 SNPs were observed to be uniquely associated to one variable:

- 100SW: SNP3 ( $p=3.42 \mathrm{E}-05)$; SNP4 $(p=7.69 \mathrm{E}-05)$; SNP55 ( $p=5.01 \mathrm{E}-06) ; \operatorname{SNP} 87$ ( $p=7.23 \mathrm{E}-05)$; SNP99 $(p=$ 2.80E-06); SNP100 ( $p=5.86 \mathrm{E}-05)$; SNP109 ( $p=1.04 \mathrm{E}-$ $04)$; SNP113 ( $p=2.26 \mathrm{E}-04)$; SNP165 ( $p=7.23 \mathrm{E}-04)$; $\operatorname{SNP} 167(p=9.10 \mathrm{E}-04)$.
TABLE 1 | Total SNPs associated to phenotypes by genetic model testing.

\begin{tabular}{lccccc}
\hline Trait & Codominant Dominant Recessive Overdominant & $\begin{array}{c}\text { log- } \\
\text { additive }\end{array}$ & Total \\
& & & & & \\
\hline SY & & & & 8 & 19 \\
100SW & 2 & 9 & 12 & 1 & 58 \\
DF & 41 & 4 & 2 & 1 & 8 \\
DPM & 2 & 3 & 9 & & 42 \\
RP & 32 & 1 & 2 & & 8 \\
PB & 6 & & 4 & 2 & 44 \\
SB & 37 & 1 & 4 & 1 & 40 \\
TB & 35 & & 1 & 1 & 1 \\
RI & 35 & & & 1 & 0 \\
HI & & & 34 & 15 & 257 \\
\hline Total & 190 & 18 & & & \\
\hline
\end{tabular}

Row labels are: SY, seed yield; 100SW, weight of 100 seeds; DF, days to flowering; DPM, days to physiological maturity; $R P$, reproductive period; $P B$, plant biomass; $S B$, seed biomass; TB, total biomass; $R I$, reuse index; HI, harvest index. Only statistical significant $(P<0.0003)$ SNPs are counted.

- DF: SNP16 ( $p=8.52 \mathrm{E}-05)$; SNP33 ( $p=9.49 \mathrm{E}-05)$; SNP35 $(p=2.26 \mathrm{E}-06)$; SNP38 $(p=9.02 \mathrm{E}-05)$; SNP39 $(p=1.17 \mathrm{E}-$ $04)$; SNP40 ( $p=3.37 \mathrm{E}-06)$; SNP41 ( $p=2.43 \mathrm{E}-06)$; SNP43 $(p=5.72 \mathrm{E}-04)$; SNP54 $(p=6.53 \mathrm{E}-04)$.

- DPM: SNP118 ( $p=6.09 \mathrm{E}-04)$.

- SB: SNP21 ( $p=1.20 \mathrm{E}-04)$.

Eighteen SNPs were associated to two variables:

- SNP9, SNP155 with DF and DPM.

- SNP94, SNP133, SNP142 with 100SW and DPM.

- SNP112, SNP114 with $100 \mathrm{SW}$ and DF.

- SNP160 with PB and TB.

- SNP17, SNP107, SNP110, SNP122, SNP123, SNP128, SNP150 with RP and DF.

- SNP69 with RI and SB.

- SNP19 with DF and SB.

- SNP106 with DF and RP.

Particularly, high correlations were observed between five variables (DF, PR, SB, TB, and RI); SB, TB, and RI with 30 SNPs (SNP5, 7, 24, 26, 27, 28, 29, 30, 31, 32, 36, 56, 57, 59, 60, 61, 62, $63,74,75,77,79,80,81,90,91,98,115,120$, and 145$)$.

\section{SNP Functional Annotation}

SNP probes were aligned in the reference genome and annotated using Blast, InterproScan and Gene Ontology with Blast2GO (Conesa et al., 2005) to identify the gene being impacted by the SNP. Thirty-seven out of 83 SNPs could be identified and associated with a phenotype in a Gene Ontology class (biological process, cellular component or molecular function; BP, CC, and MF, respectively); a detailed table is shown in Supplementary Table 5.

The functional annotation could reveal a putative role of some genes. For example, SNP18, which was strongly associated with biomass, is localized in the gene Phvul.009G226700.1. This gene encodes a putative aldehyde dehydrogenase (NAD), which has 
TABLE 2 | SNPs associated to phenotypes.

\begin{tabular}{|c|c|c|c|c|c|c|c|c|c|c|}
\hline SNP & & & & Traits & & & & & & Total \\
\hline 3 & $100 S W$ & & & & & & & & & 1 \\
\hline 4 & $100 S W$ & & & & & & & & & 1 \\
\hline 5 & & DF & & $\mathrm{RP}$ & & SB & TB & $\mathrm{Rl}$ & & 5 \\
\hline 6 & & DF & & $\mathrm{RP}$ & & SB & TB & & & 4 \\
\hline 7 & & DF & & $\mathrm{RP}$ & & SB & TB & $\mathrm{Rl}$ & & 5 \\
\hline 9 & & DF & DPM & & & & & & & 2 \\
\hline 14 & & & & & PB & SB & TB & $\mathrm{Rl}$ & & 4 \\
\hline 16 & & DF & & & & & & & & 1 \\
\hline 17 & & DF & & $\mathrm{RP}$ & & & & & & 2 \\
\hline 18 & & & & & PB & SB & TB & $\mathrm{Rl}$ & & 4 \\
\hline 19 & & DF & & & & SB & & & & 2 \\
\hline 21 & & & & & & SB & & & & 1 \\
\hline 24 & & DF & & $\mathrm{RP}$ & & SB & TB & $\mathrm{RI}$ & & 5 \\
\hline 25 & & & & & PB & SB & TB & $\mathrm{Rl}$ & & 4 \\
\hline 26 & & DF & & $\mathrm{RP}$ & & SB & TB & $\mathrm{Rl}$ & & 5 \\
\hline 27 & & DF & & $\mathrm{RP}$ & & SB & TB & $\mathrm{Rl}$ & & 5 \\
\hline 28 & & DF & & $\mathrm{RP}$ & & SB & TB & $\mathrm{Rl}$ & & 5 \\
\hline 29 & & DF & & $\mathrm{RP}$ & & SB & TB & $\mathrm{Rl}$ & & 5 \\
\hline 30 & & DF & & $\mathrm{RP}$ & & SB & TB & $\mathrm{Rl}$ & & 5 \\
\hline 31 & & DF & & $\mathrm{RP}$ & & SB & TB & $\mathrm{Rl}$ & & 5 \\
\hline 32 & & DF & & $\mathrm{RP}$ & & SB & TB & $\mathrm{Rl}$ & & 5 \\
\hline 33 & & DF & & & & & & & & 1 \\
\hline 34 & & DF & & & & SB & & & $\mathrm{HI}$ & 3 \\
\hline 35 & & DF & & & & & & & & 1 \\
\hline 36 & & DF & & $\mathrm{RP}$ & & SB & TB & $\mathrm{Rl}$ & & 5 \\
\hline 38 & & DF & & & & & & & & 1 \\
\hline 39 & & DF & & & & & & & & 1 \\
\hline 40 & & DF & & & & & & & & 1 \\
\hline 41 & & DF & & & & & & & & 1 \\
\hline 43 & & DF & & & & & & & & 1 \\
\hline 49 & & & & & PB & SB & TB & $\mathrm{RI}$ & & 4 \\
\hline 54 & & DF & & & & & & & & 1 \\
\hline 55 & $100 S W$ & & & & & & & & & 1 \\
\hline 56 & & DF & & $\mathrm{RP}$ & & SB & TB & $\mathrm{Rl}$ & & 5 \\
\hline 57 & & DF & & $\mathrm{RP}$ & & SB & TB & $\mathrm{RI}$ & & 5 \\
\hline 59 & & DF & & $\mathrm{RP}$ & & SB & TB & $\mathrm{Rl}$ & & 5 \\
\hline 60 & & DF & & $\mathrm{RP}$ & & SB & TB & $\mathrm{Rl}$ & & 5 \\
\hline 61 & & DF & & $\mathrm{RP}$ & & SB & TB & $\mathrm{Rl}$ & & 5 \\
\hline 62 & & DF & & $\mathrm{RP}$ & & SB & TB & $\mathrm{Rl}$ & & 5 \\
\hline 63 & & DF & & $\mathrm{RP}$ & & SB & TB & $\mathrm{Rl}$ & & 5 \\
\hline 69 & & & & & & SB & & $\mathrm{Rl}$ & & 2 \\
\hline 70 & $100 S W$ & DF & DPM & & & & & & & 3 \\
\hline 74 & & DF & & $\mathrm{RP}$ & & SB & TB & $\mathrm{Rl}$ & & 5 \\
\hline 75 & & DF & & $\mathrm{RP}$ & & SB & TB & $\mathrm{Rl}$ & & 5 \\
\hline 76 & & & & & PB & SB & TB & $\mathrm{Rl}$ & & 4 \\
\hline 77 & & DF & & $\mathrm{RP}$ & & SB & TB & $\mathrm{Rl}$ & & 5 \\
\hline 79 & & DF & & $\mathrm{RP}$ & & SB & TB & $\mathrm{Rl}$ & & 5 \\
\hline 80 & & DF & & $\mathrm{RP}$ & & SB & TB & $\mathrm{Rl}$ & & 5 \\
\hline 81 & & DF & & $\mathrm{RP}$ & & SB & TB & $\mathrm{Rl}$ & & 5 \\
\hline 85 & $100 S W$ & DF & & $\mathrm{RP}$ & & & & & & 3 \\
\hline 87 & $100 S W$ & & & & & & & & & 1 \\
\hline 89 & $100 S W$ & & DPM & & & SB & TB & & & 4 \\
\hline
\end{tabular}

(Continued)
TABLE 2 | Continued

\begin{tabular}{|c|c|c|c|c|c|c|c|c|c|}
\hline SNP & & & & Traits & & & & & Total \\
\hline 90 & & DF & & $\mathrm{RP}$ & & SB & TB & $\mathrm{Rl}$ & 5 \\
\hline 91 & & DF & & $\mathrm{RP}$ & & SB & TB & $\mathrm{Rl}$ & 5 \\
\hline 94 & $100 \mathrm{SW}$ & & DPM & & & & & & 2 \\
\hline 97 & & & & & PB & SB & TB & $\mathrm{Rl}$ & 4 \\
\hline 98 & & DF & & $\mathrm{RP}$ & & SB & TB & $\mathrm{Rl}$ & 5 \\
\hline 99 & $100 \mathrm{SW}$ & & & & & & & & 1 \\
\hline 100 & $100 S W$ & & & & & & & & 1 \\
\hline 104 & & DF & & $\mathrm{RP}$ & & SB & & & 3 \\
\hline 106 & & DF & & $\mathrm{RP}$ & & & & & 2 \\
\hline 107 & & DF & & $\mathrm{RP}$ & & & & & 2 \\
\hline 109 & $100 S W$ & & & & & & & & 1 \\
\hline 110 & & DF & & $\mathrm{RP}$ & & & & & 2 \\
\hline 112 & $100 S W$ & DF & & & & & & & 2 \\
\hline 113 & $100 \mathrm{SW}$ & & & & & & & & 1 \\
\hline 114 & $100 S W$ & DF & & & & & & & 2 \\
\hline 115 & & DF & & $\mathrm{RP}$ & & SB & TB & $\mathrm{Rl}$ & 5 \\
\hline 118 & & & DPM & & & & & & 1 \\
\hline 120 & & DF & & $\mathrm{RP}$ & & SB & TB & $\mathrm{Rl}$ & 5 \\
\hline 122 & & DF & & $\mathrm{RP}$ & & & & & 2 \\
\hline 123 & & DF & & $\mathrm{RP}$ & & & & & 2 \\
\hline 128 & & DF & & $\mathrm{RP}$ & & & & & 2 \\
\hline 133 & $100 S W$ & & DPM & & & & & & 2 \\
\hline 136 & & & & & PB & SB & TB & & 3 \\
\hline 142 & $100 S W$ & & DPM & & & & & & 2 \\
\hline 145 & & DF & & $\mathrm{RP}$ & & SB & TB & $\mathrm{Rl}$ & 5 \\
\hline 148 & $100 \mathrm{SW}$ & DF & & $\mathrm{RP}$ & & & & & 3 \\
\hline 150 & & DF & & $\mathrm{RP}$ & & & & & 2 \\
\hline 155 & & DF & DPM & & & & & & 2 \\
\hline 160 & & & & & PB & & TB & & 2 \\
\hline 165 & 100SW & & & & & & & & 1 \\
\hline 167 & $100 S W$ & & & & & & & & 1 \\
\hline Tota & 19 & 58 & 8 & 42 & 8 & 44 & 40 & 37 & 257 \\
\hline
\end{tabular}

SNPS with significant association per trail $(P<0.0003)$ are showed. Trait labels are: $100 S W$, weight of 100 seeds; DF, days to flowering; DPM, days to physiological maturity; $H I$, harvest index; $P B$, plant biomass; $R I$, reuse index; $R P$, reproductive period; $S B$, seed biomass; SY, seed yield; TB, total biomass.

been involved in oxidation-reduction process in the response to abiotic stresses (salinity and desiccation) in an abscisic acid (ABA)-mediated response.

Another group of SNPs were associated with kinase proteins, such as SNP9, SNP61, SNP106, and SNP115.

Some SNPs were involved in starch biosynthesis, including genes Phvul.001G230000.1 and Phvul.011G089900.1, containing SNP28 and SNP128, respectively.

We also found several SNPs $(14,38,40,76,90,97,99,100$, 104,107 , and 118) that are localized in genes with a putative molecular function of protein binding. Many of them could be associated with signal transduction and may be transcription factors modulating gene expression.

The remaining SNPs had unclear stress-related biological function. For example, SNP16 was localized in actin nucleation; SNP35 was related to postreplication protein repair; SNP49 
was in a GTPase; SNP56 with gene regulation in peroxisomes; SNP60 was a putative acyl-transferase; SNP62 and SNP113 were membrane proteins; SNP75, SNP91, SNP120, SNP122, and SNP124 were intracellular transport proteins; SNP80 and SNP98 were associated in transcription regulation; SNP112 was identified as a methyl-transferase in rRNA.

We tested the SNPs functional impact in their respective protein. Seven out of 37 SNPs caused a non-synonymous mutation, but their impact in protein product was neutral or inconclusive as predicted by PredictSNP. Five SNPs are synonymous (silent mutations). The rest, 25 SNPs were localized outside exons making their interpretation harder (Supplementary Table 3).

\section{Discussion}

All plants can be affected by drought at some time during growth because of rainfall variability, water retention in soil, salinity, and extreme temperatures (Chaves et al., 2003). Effects of drought may increase as global climate increases arid areas. Plants have developed response mechanisms to drought stress at the morphological, anatomical, and cellular levels (Chaves et al., 2003; Shinozaki and Yamaguchi-Shinozaki, 2007). Those mechanisms involve increase in water absorption and environment adaptation to reduce leave area and increase root area (Potters et al., 2007; Shao et al., 2008). The responses regulate the expression of several genes including enzymes for antioxidants and osmolite metabolism, signaling proteins such as kinases and transcription factors (Xiong et al., 2002; Chaves et al., 2003). Another physiological resistance mechanism is stoma closure (Taiz and Zeiger, 2006), which is mediate by the phytohormone ABA (Zhang et al., 2006). The ABA is a plant hormone that modulates several stress responses. ABA production in drought is important to initialize early responses to survive the hydric stress (Zhang et al., 2006). As a hormone, ABA is used to communicate with other plants the general stress mode. Besides ABA-related modulation, this gene could be associated with general amino acids production for arginine, histidine, tryptophan, alanine, and proline. Proline is a known amino acid used for osmotic protection for cells in drought stress (Camacho Barrón and González de Mejía, 1998; Ashraf and Foolad, 2007).

Our approach was limited by the size of the population and amount of SNPs tested, making non-optimal for a structured QTL nor as extensive in a tolerant-sensible lines in GWAS. However, the SMA revealed some interesting genes for further validation. In our analysis we found 83 SNPs to be statistically associated to phenotypic traits. After the functional annotation of the respective genes containing those SNPs, we can assign a function to 37 of those genes. Some had a clear function in stress response or tolerance. Plant responses to drought are modulated by diverse physiological mechanisms, which are in general controlled by multiple genes (Foolad, 2004).

The SNP18 is localized in the gene Phvul.009G226700.1, a gene involved in ABA regulation based on its similarity (78\%) with ALDH7B4 (AT1G54100) gene in Arabidopsis (Kirch et al., 2005). ABA regulates two basic processes in plant development: (1) seed maturation and germination modulated by nutrient accumulation and seed dormancy (Chen et al., 2015); (2) plant responses to abiotic stresses, including drought (Zhang et al., 2006). ABA is a key molecule to modulate and resist drought stress, and its level is balanced with high precision with photosynthesis. In Arabidopsis, AtBG1 protein modulates ABA endogenous levels (Hirayama and Shinozaki, 2007); this gene and several cyp707a genes are induced by drought and recovery (Saito et al., 2004). Razem et al. (2006) reported putative ABA receptors interacting with FCA protein to modulate flowering time. Another studies in gene promoters and ABA-mutants in Arabidopsis showed the role for ABA modulating the drought stress responses (Shinozaki and Yamaguchi-Shinozaki, 2000; Xiong et al., 2002). Besides ABA regulation, this gene is also involved in amino acids biosynthesis. As mentioned before, some amino acids such proline are considered osmolites, therefore their biosynthesis is also increased as a drought response (Ashraf and Foolad, 2007). Proline accumulation, besides osmotic regulation, protects cell membrane and membrane proteins from dehydration and free radicals (Yamaguchi-Shinozaki and Shinozaki, 2006; Ashraf and Foolad, 2007).

We also found SNP28 and SNP128 localized in genes Phvul.001G230000.1 and Phvul.011G089900.1 respectively; these genes are involved in osmotic level regulation by starch biosynthesis. The increase in starch production has been correlated to positive resistance to drought in plants (Krasensky and Jonak, 2012).

In osmotic regulation, water is introduced into the cell by biosynthesis of low molecular weight osmolites (such as carbohydrates, methylamines, free amino acids, and amino acid derivate) and ion accumulation (such as $\mathrm{K}^{+}$and $\mathrm{Na}^{+}$) (Cushman, 2001). Osmolites accumulation protects cells from reactive oxygen species (ROS) (Pinhero et al., 1997). Osmolite biosynthesis gene overexpression has been used to protect plant from osmotic stress in several species (Garg et al., 2002; Abebe et al., 2003; Hmida-Sayari et al., 2005; Waditee et al., 2005; Ashraf and Foolad, 2007).

We also identified SNP39, SNP136, and SNP142 that localized in genes Phvul.002G322400.1, Phvul.009G215600.1, and Phvul.010G038200.1, respectively. Those genes are related to ROS, which are generated by an increase in $\mathrm{O}_{2}$ photoreduction in chloroplasts (Laloi et al., 2004).

Other commonly induced genes in drought stress are kinases, and we identified SNPs in kinase genes (including SNP9, SNP38, SNP61, SNP99, SNP100, SNP106, SNP115, and SNP142). Kinases are important proteins in signal transport as key proteins for regulation and propagation of stress signals including drought (Umezawa et al., 2006). SNP61 (in the sequence of Phvul.006G097800.1) is associated with myosin heavy chain phosphorylation, which is important in lateral root formation, a common physiological response in this stress. Previous studies in Arabidopsis shown a connection between PP2C and a kinase related to SNF1 (sucrose non-fermenting1-related protein kinase or SnRKs), in particular with kinases SnRK2 and SnRK3. Genetic and biochemical studies have demonstrated that a function for SnRK2 is stoma movement, gene expression as response to $\mathrm{ABA}$ and $\mathrm{ABA}$ responses in drought stress and germination (Fujii et al., 2007). Other kinase identified in 
wheat is TaSnRK2.8, an SnRK2 (sucrose non-fermenting1related protein kinase 2) member of wheat. TaSnRK2.8 confers enhanced multi-stress tolerances in carbohydrate metabolism. SNPs in the TaSnRK2.8-A-C region demonstrated that the nucleotide diversity in SNPs was significantly associated with seedling biomass under normal conditions, plant height, flag leaf width, and water-soluble carbohydrate content under drought conditions. Based on the SNP identified, a functional marker of TaSnRK2.8-A-C was developed, that could be utilized in wheat breeding programs aimed at improving seedling biomass and water-soluble carbohydrates, and consequently to enhance stress resistance in wheat (Zhang et al., 2013).

We also found SNP120 in a Late Embryogenesis Abundant Proteins (LEA) gene (Phvul.004G005200.1). LEA genes protect membrane proteins and cell membrane from dehydration; also they are related to osmolite biosynthesis and have antioxidative function (Xiong et al., 2002; Kotchoni and Bartles, 2003).

Another interesting gene is SNP80, localized in the gene Phvul.006G087000.1, a putative transcription factor (TF). The role of TFs is to modulate gene expression binding to specific DNA sites in promoter regions. Previous reports have identified several TFs involved in drought responses (Finkelstein and Lynch, 2000; Nicolas et al., 2014) and their overexpression could increase tolerance to the stress (Garg et al., 2002; Abebe et al., 2003; Shinozaki et al., 2003; Hmida-Sayari et al., 2005; Waditee et al., 2005; Yamaguchi-Shinozaki and Shinozaki, 2005; Ashraf and Foolad, 2007).

Thirty-seven out of 83 SNPs were localized inside coding genes, but functional impact of SNPs is a challenge in each case. We didn't observe a clear functional impact because some SNPs are outside exon or produce synonymous or neutral mutations. It cannot be fully explained without further research.

In the case of common bean (Phaseolus vulgaris L.) there are few studies related to genotyping and association to abiotic stresses. Some of these SNPs reported here may be used as markers in MAS to support breeders in the selection of plants with drought resistance without reduction of production, following validation of drought tolerance association in an independent study.

MAS in plants can be implemented quickly and efficiently (Rafalski, 2002). The use of GWAS to identify genes leading to drought tolerance will not identify useful sequence changes

\section{References}

Abebe, T., Guenzi, A. C., Martin, B., and Cushman, J. C. (2003). Tolerance of manitol-accumulating transgenic wheat to water stress and salinity. Plant Physiol. 131, 1748-1755. doi: 10.1104/pp.102. 003616

Acosta-Díaz, E., Trejo-López, C., Ruiz-Posadas, L. M., Padilla-Ramírez, J. S., and Acosta Gallegos, J. A. (2004). Adaptation of common bean to drought stress during the reproductive stage. Terra Latinoamer. 22, 49-58.

Acosta-Gallegos, J. A., Ochoa-Márquez, R., Arrieta-Montiel, M. P., Ibarra-Pérez, F., Pajarito-Ravelero, A., and Sánchez-Valdez, I. (1995). Registration of 'Pinto Villa' common bean. Crop Sci. 35, 1211. doi: 10.2135/cropsci1995.0011183X003500040062x if they work via post-transcriptional modifications, which have been shown to have an important role in stress adaptation as in cold (Chinnusamy et al., 2007).

We are working in the development of techniques for easy, quick, and reproducible allele specific marker detection (ASM) to be used in MAS programs for common bean (Collard and Mackill, 2008). Simple techniques such as PCR allele specific amplification can be used in large-scale genotyping of droughtresistant lines as in previous works (Wei et al., 2006; Liu et al., 2012). The efficiency of MAS is reduced by marker-gene recombination, low polymorphism level in parental lines, QTL resolution and genotype by environment interactions. These factors are important to researchers to identify all genetic variants in a population and choose the best markers for MAS (Elshire et al., 2011). Our results can be used as a starting point to develop new marker identification in parental lines in targeted introgression programs.

All genes identified are being studied in our group to understand how their function may provide tolerance in drought and test them in the populations and susceptible lines in future studies.

\section{Author Contributions}

EV, MG and PG conceived and designed the project, JA support with expertise and cultivars for common bean lines, EV conducted all experiments, EV and JC performed the data analyzes and biological interpretation. All authors wrote the manuscript.

\section{Acknowledgments}

The authors would like to recognize the economic support of the Generation Challene Program (a CGIAR Challenge Programme). The authors would like to thank the three anonymous reviewers for improving the manuscript quality.

\section{Supplementary Material}

The Supplementary Material for this article can be found online at: http://journal.frontiersin.org/article/10.3389/fpls.2015. 00546

Ashraf, M., and Foolad, M. R. (2007). Roles of glycine betaine and proline in improving plant abiotic stress resistance. Environ. Exp. Bot. 59, 206-216. doi: 10.1016/j.envexpbot.2005.12.006

Beebe, S. E., Rao, I. M., Blair, M. W., and Acosta-Gallegos, J. A. (2013). Phenotyping common beans for adaptation to drought. Front. Physiol. 4:35. doi: 10.3389/fphys.2013.00035

Beebe, S. E., Rao, I. M., Cajiao, C., and Grajales, M. (2008). Selection for drought resistance in common bean also improves yield in phosphorus limited and favorable environments. Crop Sci. 48, 582-592. doi: 10.2135/cropsci2007.07.0404

Bendl, J., Stourac, J., Salanda, O., Pavelka, A., Wieben, E. D., Zendulka, J., et al. (2014). PredictSNP: robust and accurate consensus classifier for prediction of disease-related mutations. PLoS Comput. Biol. 10:e1003440. doi: 10.1371/journal.pcbi.1003440 
Bitocchi, E., Bellucci, E., Giardini, A., Rau, D., Rodriguez, M., Biagetti, E., et al. (2013). Molecular analysis of the parallel domestication of the common bean (Phaseolus vulgaris) in Mesoamerica. New Phytol. 197, 300-313. doi: 10.1111/j.1469-8137.2012.04377.x

Blair, M. W., Díaz, L. M., Buendía, H. F., and Duque, M. C. (2009). Genetic diversity, seed size associations and population structure of a core collection of common beans (Phaseolus vulgaris L.). Theor. Appl. Genet. 119, 955-972. doi: 10.1007/s00122-009-1064-8

Blair, M. W., Giraldo, M. C., Buendía, H. F., Tovar, E., Duque, M. C., and Beebe, S. E. (2006). Microsatellite marker diversity in common bean (Phaseolus vulgaris L.). Theor. Appl. Genet. 113, 100-109. doi: 10.1007/s00122-006-0276-4

Blum, A. (2005). Drought resistance, water-use efficiency, and yield potentialare they compatible, dissonant, or mutually exclusive? Aust. J. Agric. Res. 56, 1159-1168. doi: 10.1071/AR05069

Broughton, W. J., Hernández, G., Blair, M. W., Beebe, S., Gepts, P., and Vanderleyden, J. (2003). Beans (Phaseolus spp.)-model food legumes. Plant Soil 252, 55-128. doi: 10.1023/A:1024146710611

Camacho Barrón, M., and González de Mejía, E. (1998). Comparative study of enzymes related to proline metabolism in tepary bean (Phaseolus acutifolius) and common bean (Phaseolus vulgaris) under drought and irrigated conditions, and various urea concentrations. Plant Foods Hum. Nutr. 52, 119-132. doi: 10.1023/A:1008011529258

Cavalieri, A., Merchant, A., and van Volkenburgh, E. (2011). Why not beans? Funct. Plant Biol. 38, iii-vi. doi: 10.1071/FPv38n12_FO

Chaves, M. M., Maroco, J. P., and Pereira, J. S. (2003). Understanding plant responses to drought-from genes to the whole plant. Funct. Plant Biol. 30, 239-264. doi: 10.1071/FP02076

Chen, C., Twito, S., and Miller, G. (2015). New cross talk between ROS, ABA and auxin controlling seed maturation and germination unraveled in APX6 deficient Arabidopsis seeds. Plant Signal Behav. 9:e976489. doi: $10.4161 / 15592324.2014 .976489$

Chinnusamy, V., Zhu, J., and Zhu, J. K. (2007). Cold stress regulation of gene expression in plants. Trends Plant Sci. 12, 444-451. doi: 10.1016/j.tplants.2007.07.002

Collard, B. C. Y., and Mackill, D. J. (2008). Marker-assisted selection: an approach for precision plant breeding in the twenty-first century. Philos. Trans. R. Soc. B. 363, 557-572. doi: 10.1098/rstb.2007.2170

Conesa, A., Götz, S., García-Gómez, J. M., Terol, J., Talón, M., and Robles, M. (2005). Blast2GO: a universal tool for annotation, visualization and analysis in functional genomics research. Bioinformatics 21, 3674-3676. doi: 10.1093/bioinformatics/bti610

Cortés, A. J., Chavarro, M. C., and Blair, M. W. (2011). SNP marker diversity in common bean (Phaseolus vulgaris L.). Theor. Appl. Genet. 123, 827-845. doi: $10.1007 / \mathrm{s} 00122-011-1630-8$

Cushman, J. C. (2001). Osmoregulation in plants: implications for agriculture. Amer. Zool. 41, 758-769. doi: 10.1668/0003-1569(2001)041[0758:OIPIFA] 2.0.CO;2

Díaz, L. M., and Blair, M. W. (2006). Race structure within the Mesoamerican gene pool of common bean (Phaseolus vulgaris L.) as determined by microsatellite markers. Theor. Appl. Genet. 114, 143-154. doi: 10.1007/s00122-006-0417-9

Earl, H. J. (2003). A precise gravimetric method for simulating drought stress in pot experiments. Crop Sci. 43, 1868-1873. doi: 10.2135/cropsci2003.1868

Elshire, R. J., Glaubitz, J. C., Sun, Q., Poland, J. A., Kawamoto, K., Buckler, E. S., et al. (2011). A robust, simple genotyping-by-sequencing (GBS) approach for high diversity species. PLoS ONE 6:e19379. doi: 10.1371/journal.pone.0019379

Finkelstein, R. R., and Lynch, T. J. (2000). The Arabidopsis abscisic acid response gene ABI5 encodes a basic leucine zipper transcription factor. Plant Cell 12, 599-609. doi: 10.1105/tpc.12.4.599

Foolad, M. R. (2004). Recent advances in genetics of salt tolerance in tomato. Plant Cell Tissue Organ Cult. 76, 101-119. doi: 10.1023/B:TICU.0000007308.47608.88

Fujii, H., Verslues, P. E., and Zhu, J. K. (2007). Identification of two protein kinases required for abscisic acid regulation of seed germination, root growth, and gene expression in Arabidopsis. Plant Cell 19, 485-494. doi: 10.1105/tpc.106.048538

Gaitán-Solís, E., Choi, I. Y., Quigley, C., Cregan, P., and Tohme, J. (2008). Single nucleotide polymorphisms in common bean: their discovery and genotyping using a multiplex detection system. Plant Genome 1, 125-134. doi: 10.3835/plantgenome2008.04.0204

Galeano, C. H., Cortés, A. J., Fernández, A. C., Soler, Á., Franco-Herrera, N., Makunde, G., et al. (2012). Gene-based single nucleotide polymorphism markers for genetic and association mapping in common bean. BMC Genet. 13:48. doi: 10.1186/1471-2156-13-48

Galeano, C. H., Fernández, A. C., Gómez, M., and Blair, M. W. (2009a). Single strand conformation polymorphism based SNP and Indel markers for genetic mapping and synteny analysis of common bean (Phaseolus vulgaris L.). BMC Genomics 10:629. doi: 10.1186/1471-2164-10-629

Galeano, C. H., Gomez, M., Rodriguez, L. M., and Blair, M. W. (2009b). CEL I nuclease digestion for SNP discovery and marker development in common bean (Phaseolus vulgaris L.). Crop Sci. 49, 381-394. doi: 10.2135/cropsci2008.07.0413

Garg, A. K., Kim, J. K., Owens, T. G., Ranwala, A. P., Choi, Y. D., Kochian, L. V. et al. (2002). Trehalose accumulation in rice plants confers high tolerance levels to different abiotic stresses. Proc. Natl. Acad. Sci. U.S.A. 99, 15898-15903. doi: $10.1073 /$ pnas.252637799

Gepts, P. (1998). Origin and evolution of common bean: past events and recent trends. HortSci 33, 1124-1130.

González, J. R., Armengol, L., Solé, X., Guinó, E., Mercader, J. M., Estivill, X., et al. (2007). SNPassoc: an R package to perform whole genome association studies. Bioinformatics 23, 644-645. doi: 10.1093/bioinformatics/btm025

Goretti, D., Bitocchi, E., Bellucci, E., Rodriguez, M., Rau, D., Gioia, T., et al. (2014). Development of single nucleotide polymorphisms in Phaseolus vulgaris and related Phaseolus spp. Mol. Breed. 33, 531-544. doi: 10.1007/s11032-013-9970-5

Gupta, P. K., Rustgi, S., and Mir, R. R. (2008). Array-based highthroughput DNA markers for crop improvement. Heredity 101, 5-18. doi: 10.1038/hdy.2008.35

Hirayama, T., and Shinozaki, K. (2007). Perception and transduction of abscisic acid signals: key to the function of the versatile plant hormone ABA. Trends Plant Sci. 12, 343-351. doi: 10.1016/j.tplants.2007.06.013

Hmida-Sayari, A., Gargouri-Bouzid, R., Bidani, A., Jaoua, L., Savoure, A., and Jaoua, S. (2005). Overexpression of $\Delta^{1}$-pyrroline-5-carboxylate synthetase increases proline production and confers salt tolerance in transgenic potato plants. Plant Sci. 169, 746-752. doi: 10.1016/j.plantsci.2005.05.025

Hormozdiari, F., Kostem, E., Yong Kang, E., Pasaniuc, B., and Eskin, E. (2014). Identifying causal variants at loci with multiple signals of association. Genetics 198, 497-508. doi: 10.1534/genetics.114.167908

Hyten, D., Song, Q., Fickus, E. W., Quigley, C. V., Lim, J. S., Choi, I. Y., et al. (2010). High-throughput SNP discovery and assay development in common bean. BMC Genomics 11:475. doi: 10.1186/1471-2164-11-475

Jimenez-Galindo, J. C., and Acosta-Gallegos, J. A. (2013). Evaluation of the yield of common (Phaseolus vulgaris L.) and Tepary (Phaseolus acutifolius A. Gray) beans with the irrigation-drought method in Chihuahua. Rev. Mex. Cienc. Agríc. 4, 557-567. Available online at: http://www.redalyc.org/articulo.oa?id= 263127562006

Kirch, H. H., Schlingensiepen, S., Kotchoni, S., Sunkar, R., and Bartels, D. (2005). Detailed expression analysis of selected genes of the aldehyde dehydrogenase (ALDH) gene superfamily in Arabidopsis thaliana. Plant Mol. Biol. 57, 315-332. doi: 10.1007/s11103-004-7796-6

Kotchoni, S. O., and Bartles, D. (2003). Water stress induces the up-regulation of a specific set of gens in plants: Aldehyde dehydrogenases as an example. Bul. J. Plant Physiol. Special Issue, 2003, 37-51. Available online at: http://www.bio21. bas.bg/ipp/gapbfiles/essa-03/03_essa_37-51.pdf

Krasensky, J., and Jonak, C. (2012). Drought, salt, and temperature stress-induced metabolic rearrangements and regulatory networks. J. Exp. Bot. 63, 1593-1608. doi: $10.1093 /$ jxb/err460

Kwak, M., and Gepts, P. (2009). Structure of genetic diversity in the two major gene pools of common bean (Phaseolus vulgaris L., Fabaceae). Theor. Appl. Genet. 118, 979-992. doi: 10.1007/s00122-008-0955-4

Laloi, C., Apel, K., and Danon, A. (2004). Reactive oxygen signalling: the latest news. Curr. Opin. Plant Biol. 7, 323-328. doi: 10.1016/j.pbi.2004.03.005

Liu, J., Huang, S., Sun, M., Liu, S., Liu, Y., Wang, W., et al. (2012). An improved allele-specific PCR primer design method for SNP marker analysis and its application. Plant Methods 8:34. doi: 10.1186/1746-4811-8-34

Mamidi, S., Rossi, M., Annam, D., Moghaddam, S., Lee, R., Papa, R., et al. (2011). Investigation of the domestication of common bean (Phaseolus vulgaris) using multilocus sequence data. Funct. Plant Biol. 38, 953-967. doi: 10.1071/ FP11124

McClean, P. E., Burridge, J., Beebe, S., Rao, I. M., and Porch, T. G. (2011). Crop improvement in the era of climate change: an integrated, multi-disciplinary approach for common bean (Phaseolus vulgaris). Funct. Plant Biol. 38, 927-933. doi: 10.1071/FP11102 
Mukeshimana, G., Butare, L., Cregan, P. B., Blair, M. W., and Kelly, J. D. (2014). Quantitative trait loci associated with drought tolerance in common bean. Crop Sci. 54, 1-16. doi: 10.2135/cropsci2013.06.0427

Muñoz-Perea, C. G., Terán, H., Allen, R. G., Wright, J. L., Westermann, D. T., and Singh, S. P. (2006). Selection for drought resistance in dry bean landraces and cultivars. Crop Sci. 46, 2111-2120. doi: 10.2135/cropsci2006.01.0029

Nakayama, N., Saneoka, H., Moghaieb, R. E. A., Premachandra, G. S., and Fujita, K. (2007). Response of growth, photosynthetic gas exchange, translocation of ${ }^{13} \mathrm{C}$-labelled photosynthate and $\mathrm{N}$ accumulation in two soybean (Glycine max L. Merrill) cultivars to drought stress. Int. J. Agric. Biol. 9, 669-674. Available online at: http://www.fspublishers.org/published_papers/38750_..pdf

Nicolas, P., Lecourieux, D., Kappel, C., Cluzet, S., Cramer, G., Delrot, S., et al. (2014). The basic leucine zipper transcription factor ABSCISIC ACID RESPONSE ELEMENT-BINDING FACTOR2 is an important transcriptional regulator of abscisic acid-dependent grape berry ripening processes1[W][OPEN]. Plant Physiol. 164, 365-383. doi: $10.1104 /$ pp.113.231977

Pearson, W. R., and Lipman, D. J. (1988). Improved tools for biological sequence comparison. Proc. Natl. Acad. Sci. U.S.A. 85, 2444-2448. doi: 10.1073/pnas.85.8.2444

Pinhero, R. G., Rao, M. V., Paliyath, G., Murr, D. P., and Fletcher, R. A. (1997). Changes in the activities of antioxidant enzymes and their relationship to genetic and paclobutrazol-induced chilling tolerance of maize seedlings. Plant Physiol. 114, 695-704.

Polanía, J. E., Rao, I., Mejía, S., Beebe, S. E., and Cajiao, C. (2012). Características morfo-fisiológicas de frijol común (Phaseolus vulgaris L.) relacionadas con la adaptación a sequía. Acta Agronómica 61, 197-206. Available online at: http://www.revistas.unal.edu.co/index.php/acta_agronomica/article/view/3752 6/39911

Potters, G., Pasternak, T. P., Guisez, Y., Palme, K. J., and Jansen, M. A. K. (2007). Stress-induced morphogenic responses: growing out of trouble? Trends Plant Sci. 12, 98-105. doi: 10.1016/j.tplants.2007.01.004

Rafalski, A. (2002). Applications of single nucleotide polymorphisms in crop genetics. Curr. Opin. Plant Biol. 5, 94-100. doi: 10.1016/S1369-5266(02) 00240-6

Rao, I. M. (2001). "Role of physiology in improving crop adaptation to abiotic stresses in the tropics: the case of common bean and tropical forages," in Handbook of Plant and Crop Physiology, ed M. Pessarakli (New York, NY: Marcel Dekker), 583-613.

Razem, F. A., El-Kereamy, E., Abrams, S. R., and Hill, R. D. (2006). The RNAbinding protein FCA is an abscisic acid receptor. Nature 439, 290-294. doi: 10.1038/nature04373

Rosales-Serna, R., Kohashi-Shibata, J., Acosta-Gallegos, J. A., Trejo-Lopez, C., Ortiz-Cereceres, J., and Kelly, J. D. (2004). Biomass distribution, maturity acceleration and yield in drought-stressed common bean cultivars. Field Crops Res. 85, 203-211. doi: 10.1016/S0378-4290(03)00161-8

Saito, S., Hirai, N., Matsumoto, C., Ohigashi, H., Ohta, D., Sakata, K., et al. (2004). Arabidopsis CYP707As Encode (+)-Abscisic acid 8' -hydroxylase, a key enzyme in the oxidative catabolism of abscisic acid. Plant Physiol. 134, 1439-1449. doi: 10.1104/pp.103.037614

Sánchez-Valdez, I., Acosta-Gallegos, J. A., Ibarra-Pérez, F. J., Rosales-Serna, R., and Singh, S. P. (2004). Registration of 'Pinto Saltillo' common bean. Crop Sci. 44, 1865-1866. doi: 10.2135/cropsci2004.1865a

Schmutz, J., McClean, P. E., Mamidi, S., Wu, G. A., Cannon, S. B., Grimwood, J., et al. (2014). A reference genome for common bean and genome-wide analysis of dual domestications. Nat. Genet. 46, 707-713. doi: 10.1038/ng.3008

Shao, H. B., Chu, L. Y., Jaleel, C. A., and Zhao, C. X. (2008). Water-deficit stressinduced anatomical changes in higher plants. C. R. Biol. 331, 215-225. doi: 10.1016/j.crvi.2008.01.002

Shi, C., Navabi, A., and Yu, K. (2011). Association mapping of common bacterial blight resistance QTL in Ontario bean breeding populations. BMC Plant Biol. 11:52. doi: 10.1186/1471-2229-11-52

Shinozaki, K., and Yamaguchi-Shinozaki, K. (2000). Molecular responses to dehydration and low temperature: differences and cross-talk between two stress signaling pathways. Curr. Opin. Plant Biol. 3, 217-223. doi: 10.1016/S13695266(00)00067-4

Shinozaki, K., and Yamaguchi-Shinozaki, K. (2007). Gene networks involved in drought stress response and tolerance. J. Exp. Bot. 58, 221-227. doi: $10.1093 / \mathrm{jxb} / \mathrm{erl} 164$
Shinozaki, K., Yamaguchi-Shinozaki, K., and Seki, M. (2003). Regulatory network of gene expression in the drought and cold stress responses. Curr. Opin. Plant Biol. 6, 410-417. doi: 10.1016/S1369-5266(03) 00092-X

Singh, S. P. (2007). Drought resistance in the race Durango dry bean landraces and cultivars. Agron. J. 99, 1219-1225. doi: 10.2134/agronj2006.0301

Singh, S. P., Gepts, P., and Debouck, D. G. (1991). Races of common bean (Phaseolus vulgaris, Fabaceae). Econ. Bot. 45, 379-396. doi: 10.1007/BF02887079

Taiz, L., and Zeiger, E. (2006). Plant Physiology. Sunderland, MA: Sinauer Associate Press.

Terán, H., and Singh, S. P. (2002a). Comparison of sources and lines selected for drought resistance in common bean. Crop Sci. 42, 64-70. doi: $10.2135 /$ cropsci2002.0064

Terán, H., and Singh, S. P. (2002b). Selection for drought resistance in early generations of common bean populations. Can. J. Plant Sci. 82, 491-497. doi: 10.4141/P01-134

Thung, M., and Rao, I. M. (1999). "Integrated management of abiotic stresses," in Common Bean Improvement in the Twenty-first Century, ed S.P. Singh (Dordrecht: Kluwer Academic Publishers), 331-370. doi: 10.1007/978-94-0159211-6_13

Umezawa, T., Fujita, M., Fujita, Y., Yamaguchi-Shinozaki, K., and Shinozaki, K. (2006). Engineering drought tolerance in plants: Discovering and tailoring genes to unlock the future. Curr. Opin. Biotechnol. 17, 113-122. doi: 10.1016/j.copbio.2006.02.002

Waditee, R., Bhuiyan, M. N. H., Rai, V., Aoki, K., Tanaka, Y., Hibino, T., et al. (2005). Genes for direct methylation of glycine provide high levels of glycinebetaine and abiotic-stress tolerance in Synechococcus and Arabidopsis. Proc. Natl. Acad. Sci. U.S.A. 102, 1318-1323. doi: 10.1073/pnas.040 9017102

Wei, B., Jing, R. L., Wang, C. S., and Chang, X. P. (2006). Assaying single nucleotide polymorphism in wheat (Triticum aestivum L.) with allele-specific PCR. Sci. Agric. Sin. 39, 1313-1320. Available online at: http://agris.fao.org/agris-search/ search.do? recordID $=$ CN2007000408

Xiong, L., Schumaker, K. S., and Zhu, J. K. (2002). Cell signaling during cold, drought, and salt stress. Plant Cell 14, S165-S183. doi: 10.1105/tpc.000596

Yamaguchi-Shinozaki, K., and Shinozaki, K. (2005). Organization of cis-acting regulatory elements in osmotic and cold-stress responsive promoters. Trends Plant Sci. 10, 88-94. doi: 10.1016/j.tplants.2004.12.012

Yamaguchi-Shinozaki, K., and Shinozaki, K. (2006). Transcriptional regulatory networks in cellular responses and tolerance to dehydration and cold stresses. Annu. Rev. Plant Biol. 57, 781-803. doi: 10.1146/annurev.arplant.57.032905.105444

Yan, J., Yang, X., Shah, T., Sanchez-Villeda, H., Li, J., Warburton, M., et al. (2010). High-throughput SNP genotyping with the GoldenGate assay in maize. Mol. Breed. 25, 441-451. doi: 10.1007/s11032-009-9343-2

Yuste-Lisbona, F. J., Santalla, M., Capel, C., García-Alcázar, M., De La Fuente, M., Capel, J., et al. (2012). Marker-based linkage map of Andean common bean (Phaseolus vulgaris L.) and mapping of QTLs underlying popping ability traits. BMC Plant Biol. 12:136. doi: 10.1186/1471-2229-12-136

Zhang, H., Mao, X., Zhang, J., Chang, X., and Jing, R. (2013). Singlenucleotide polymorphisms and association analysis of drought-resistance gene TaSnRK2.8 in common wheat. Plant Physiol. Biochem. 70, 174-181. doi: 10.1016/j.plaphy.2013.04.010

Zhang, J., Jia, W., Yang, J., and Ismail, A. M. (2006). Role of ABA in integrating plant responses to drought and salt stresses. Field Crops Res. 97, 111-119. doi: $10.1016 /$ j.fcr.2005.08.018

Conflict of Interest Statement: The authors declare that the research was conducted in the absence of any commercial or financial relationships that could be construed as a potential conflict of interest.

Copyright (c) 2015 Villordo-Pineda, González-Chavira, Giraldo-Carbajo, AcostaGallegos and Caballero-Pérez. This is an open-access article distributed under the terms of the Creative Commons Attribution License (CC BY). The use, distribution or reproduction in other forums is permitted, provided the original author(s) or licensor are credited and that the original publication in this journal is cited, in accordance with accepted academic practice. No use, distribution or reproduction is permitted which does not comply with these terms. 